\title{
The Challenge of Radicalization and Deradicalization in Prison; A Review on Social Dynamics Prison Officers and Terrorist Inmates
}

\author{
Saifudin Asrori ${ }^{1}$, Joharotul Jamilah ${ }^{2}$ and Muhammad Ismail ${ }^{3}$ \\ \{saifudin.asrori@uinjkt.ac.id ${ }^{1}$, joharotul.jamilah@uinjkt.ac.id², muhammad.ismail@uinjkt.ac.id ${ }^{3}$ \} \\ Universitas Islam Negeri Syarif Hidayatullah Jakarta, Indonesia ${ }^{1,2,3}$
}

\begin{abstract}
Correctional Institution as a vulnerable environment in spreading radical ideology, member recruitment and the development of extremist organizations. While, at the same time the correctional institution has the potential to de-radicalize terrorist inmates. This paper discusses the challenges of prison staff in controlling and managing the social dynamics of terrorist prisoners. Though the literature review and employing Risk-Need-Responsively as an approach model. This article build the assumption that risk can always occur at any time or the lack of willingness of prisoners to commit criminal acts against officers and other prisoners is the key to the success of rehabilitation efforts in correctional institutions. This research shows that the correctional Institution has great potential in the realization of the program of deradicalization of terrorist prisoners and at the same time does not rule out the possibility of potential as a place for the growth of radicalism.
\end{abstract}

Keywords: social dynamics, deradicalization, prison officers, terrorist inmates, Indonesia.

\section{Introduction}

Correctional Institution or prison as a vulnerable environment for spreading radical ideologies, recruiting members and developing an extremist organization [1]. Moreover, the correctional institution has the potential to deradicalizing extremist ideology and belief of terrorist prisoners. According to Hwang, one contributing factor of Poso Jihadist's disengagement is a 'humane' treatment by the Special Detachment (Detasemen Khusus/Densus) 88 police and correctional institution officers [2]. However, the study of radicalization and deradicalization in prisons focused on assessment and classification, management of supervision and placement, and implementation of the terrorist inmates' deradicalization programs [3]. These studies does not pay much attention to the influence of prison staff interventions on the social dynamics of terrorist prisoners.

Some studies have identified institutional, social and individual factors that cause radicalization in prisons, such as the dense of prison conditions, feelings of loss, violence, the need for protection and a sense of brotherhood [4]. The dense conditions of the correctional institution have an impact on excessive stress and encourage prisoners to gather together in sub-groups to compete for resources and social status. The atmosphere of rivalry and competition over resources as a path on the influence of extremist ideologies and groups. The competition between groups in turn as paves the way for charismatic extremist leaders in 
organizing social groups based on radical and extreme ideologies [5]. Thomas dan Zaitzow, shows that ideology and religion play an important role for inmates, especially for prisoners who are first imprisoned [6].

Some terrorist acts carried out by recidivists or planned 'behind the jail' have come to the attention of the government and the community in efforts to eradicate terrorism in Indonesia. The deradicalization program in prison is part of the 'soft approch' strategy to eradicate terrorists. The legal standing for the implementation of the de-radicalization program is Law No. 5 of 2018 concerning Eradication of Terrorism Crimes, Article 43 D defines deradicalization as a systematic, planned, integrated, systematic and continuous process carried out to eliminate or reduce and reverse the radical understanding of Terrorism that has taken place." The law mandates the National Counterterrorism Agency (Badan Nasional Penanggulanggan Terorisme/BNPT) as the executor and coordinator of the implementation of programs. BNPT noted there were 289 terrorist inmates scattered in 113 Correctional Institutions throughout Indonesia [7]. They are grouped based on their level of involvement in terrorist organizations namely; core groups, militants, supporters and sympathizers. Although the number of terrorist prisoners is far less than the total number of prisoners, which is 176,711 persons their presence can affect other prisoners [8]. This is due to their ability in the process of agitation, propaganda, recruitment, including radicalization of prison officers. As a result, prison actually functions as a place to rehabilitate, re-educate and re-socialize the maritime prisoners, instead it becomes a place to spread radical ideas, a conducive place for prisoners to design or plan to organize acts of terrorism.

Several terms need to be explained, radicalization is a process of devotion, maintenance, and development of extreme belief systems including the desire to use, support, or facilitate violence as a method to influence social change in society. While the deradicalization denotes to an efforts to neutralize radical notions through an interdisciplinary approach, such as law, psychology, religion, and social culture for those who are influenced or exposed to radical and non-violent understandings. They included: prisoners, ex-prisoners, radical militant individuals who had been involved, their families, sympathizers, and the general public. Disengagement is a process when a person or group of terrorists no longer acts violently and leaves the terrorist network. These changes are caused by various reasons, but generally changes occur regarding personal conditions [9]. Terrorist inmates refer to individuals convicted by the court for acts of terrorism under the state anti-terrorism laws, and as a consequence of life in prison. In this sense, the term will not include those categorized as suspected terrorists; those questioned by the police; those awaiting trial; or those who have fugitive status from acts of terrorism [10]. This paper will specifically analyze the social dynamics between prison officials and terrorist prisoners as a significant factor in determining the effectiveness of radicalism or sowing radicalism in prison.

\section{Theoretical Framework}

The study of social dynamics between prison officers and terrorist inmates aims to get a picture of the conditions of social life in prisons which are often accused of being a school of terrorism and being seedlings of radicalism and get an overview of the potential of prisons as a means of environmental de-radicalization. Generally, prison sentences are generally the most severe form of social sanctions imposed on individuals or groups for crimes or criminal acts. Durkheim defines crime as an act that violates or offends collective consciousness as a totality 
of beliefs and shared beliefs by community members as a buffer for the social system of life [11]. Penalties are imposed in various forms such as revoking individual rights, adjusting to new life, strict rules, strict schedules, and behaving appropriately. Prisoners must adhere to a set of very strict rules according to the prison system. Through these rules prisoners have a collective awareness that they are part of the prison system.

Social dynamics prison refer to the behavior of prison officer and terrorist inmates in prison, generated based on the interaction between the two groups. This view is based on the assumption that individual behavior is influenced by the behavior of other individuals. In the prison environment, officers are responsible for the social control of the military through planned or unplanned monitoring processes to maintain, educate, and even forced to comply with applicable norms and values. The ability of prison officers in controlling terrorist inmates has an impact on the process of radicalization or deradicalization in prison [12]. Based on the control-administration theory that social order in prison is the result of administrative policies and practices. Studies have shown that the ability of prison officers to regulate prisoner populations is an important element in determining the extent of violations. Also, organizational characteristics, such as overcrowding, unequal ratios between prisoners and officers, inadequate staff training, poor employee-management relations, and scarcity of resources are the causes of 'administrative damage' that have an impact on irregularities in prisons [13].

In organizational theory, control is described as the process of organizing members in an organization. Etzioni divides two forms of control namely coercive and remunerative [14]. In the study of prisons, coercive control is a mechanism that punishes or prevents deviant behavior through threats or the use of disciplinary measures or restrictions on prisoner freedom. Whereas remunerative control is encouraging prisoners to behave following applicable regulations by providing 'gifts' and resources with the aim that prisoners can adjust and reduce involvement in unlawful actions. Based on several results of the study remunerative control has a more positive impact on prisoners to comply with prison rules, thus preventing violent behavior.The question then is, how can Officers be able to carry out remunerative control without fear of being exposed to radical ideologies? This is based on the assumption that terrorist inmates can agitate, propaganda, and recruit prisoners, including the radicalization of prison officers. This research uses a Risk-Need-Responsivity approach, which is a model approach based on the assumption that the risk can always occur at any time or the lack of willingness of prisoners to commit criminal acts against officers and other prisoners is the key to the success of rehabilitation efforts in prison [15].

According to Andrews, Bonta, \& Wormith, there are several risk factors for prison officers namely criminal history of prisoners, anti-social personality, pro-criminal behavior, social support for crime, drug abuse, poor family relationships, poor family relationships, concerns with work, and lack of involvement in social activities [16]. Knowledge of the characteristics of prisoners inmates is an important part of the success of rehabilitation programs in prison. 


\section{Method}

\subsection{Discussion}

A prison become a vulnerable place for the occurrence of radicalization. The process of radicalization is defined as criminal convicts being recruited, becoming part of extremist groups in prisons, or a process of terrorist inmates becoming more radical, spreading and influencing their understanding to other prisoners. Prisoners' characteristics such as alienation, anti-social attitudes, disappointment, social isolation, and the tendency to get violence, make them captive audiences who are vulnerable to radicalization. In general, prisoners' acceptance of radical ideologies through various institutional, social and individual channels, such as inadequate prison capacity and excessive stress, group dynamics of violence and the desire for protection, friendship and kinship, are the entry points for the process of radicalization. This model is described by Liebling and Straub as 'the conveyor belt', which is the process of developing a radical interpretation of violence and terrorism [17].

Several psychological studies have identified crucial conditions that lead people to become radical, such as impulsive attitudes, thrill seeking behavior or desire for revenge, as well as responses to avenge the humiliation. Some interesting note by experts who are members of the Club of Madrid on psychological conditions, namely: (1) motives to show themselves in power to those who are helpless, there are also those whose main motive is to take revenge, but there are also those based on gaining recognition that their existence is important; (2) Leaders play a very important role in identifying external enemies; This leader will also invite those who are isolated and frustrated, if they are not willing, they will remain isolated and disadvantaged; (3) A religious fundamentalist leader can use his authority to interpret the scriptures to justify extreme acts of violence; (4) martyrdom culture contributes to suicide terrorism; (5) Many diaspora refugees and Muslim immigrants suffer from loss of self-existence, deprivation and isolation in the countries they occupy [18]. Extreme ideologies can make some of them radical, and make it easier for them to enter the path of terrorism

The conditions of inequality, as well as rapid socio-economic changes, have a direct impact on the growth of radicalism and violence. Gaps in conditions justify acts of violence and terrorism in the name of marginalization and oppression (socially and economically). The poverty factor that afflicts certain individuals or groups is considered as the main variable that contributes greatly to extremism and violence. Poor conditions coupled with poor education and high unemployment will quickly lead to social frustration which in turn triggers attitudes of aggression.

The issue of discrimination in prisons was reviewed by Marranci, after interviews with young Muslims who were being held in British prisons. Interviews were conducted to find out how life behind bars affected their Muslim identity and their experience of Islam. and his observations, the efforts made by prison officials to eradicate radicalism in British prisons, actually just make sure to nourish extremism. According to Marranci, Muslim prisoners who choose to show their true identity by wearing a cap and long beard, are even treated discriminatively. Also the reluctance of priests who are assigned to provide spiritual guidance in speaking out about Iraq and other problems of the Islamic world, makes young Muslims who are still easily influenced to learn themselves behind jails. After conducting interviews with more than 170 detainees and former Muslim prisoners, Marranci discovered the fact that no evidence led to suspicion of the prisoners assigned to the prison, that they had facilitated the radical attitude of the prisoners. Marranci's study showed that symbols had certain orientations. It not only confirms the prisoner's identity but can also lead to discrimination in prison. It is 
suspected that this discrimination arises because of mutually beneficial motives between the two interacting parties (prison officers and terrorist inmates). Such allegations are corroborated by statements of informants (ex-convicts) in a daily saying that a prison that serves as a deterrent tool for lawbreakers is nothing more than a law enforcement tool for profit [19].

The phenomenon of violence in prisons is closely related to the revocation of some prisoners' rights as a freedom, an autonomy, a good service, a heterosexual relationship.a security. The atmosphere of alienation as a result of the loss of communication with each other and the emergence of competition between prisoners in turn into a form of worry and anxiety for individuals. The loss of some prisoners' rights cannot be separated from the existence of imprisonment. According to Lamintang, imprisonment is a criminal in the form of limiting the freedom of movement of a convicted person by closing the person in a correctional institution and requiring inmates to obey all the rules and regulations that apply in the correctional institution associated with a penal act, orderly those who have violated these regulations. In addition to the loss of prisoners' rights, the problem of violence in prisons is also a problem in almost all prisons [20].

Violence in prisons can be categorized into three types; individual violence (prisoners with inmates, prisoners with warders), collective violence (riots and commotion in prisons), and violence related to regulation (due to unhealthy interactions between warders and prisoners). The main problem that often appears on the surface is the question of physical punishment. The officers consider it part of the sentence, but the prisoners see it as a form of torture. This is a small example of the processes of meaning in prison. According to Vernon Fox, riots and rebellions in prisons caused not only from prison, but also rooted from outside the prison related to community issues. There are five stages of riots and prisoners' rebellion incarcerated. First, riots arise because of incidents or cases that lead to anger and anxiety among inmates. Secondly, the leaders of the prisoners group put together a group of people into an organized force. Fourth, prisoners surrender because of the strength of security officers. Fifth, a comprehensive investigation and understanding of causes riots and rebellions in prisons [21]. Mark Colvin (2007) examines the relationship of prisoners' bad behavior in Mexican prisons with Defferential coercion and social support (DCSS) with organizational change in prisons [22]. The DCSS theory developed by Colvin et al has the utility to explain the framework of thinking about evil behavior or violence by understanding the organizational dynamics of prisons. The study of violence in prisons has also been carried out by Edgar \& O'Donnell with an emphasis on forms of violence, fraud, threats, theft, humiliation and conflict between inmates [23].

This violence is inseparable from the different understandings or meanings in the process of interaction in prisons, especially those related to discrimination and torture in prisons. Studies on violence and extremism have captured the need to look at several macro and microelements that lie behind why individuals and groups join extreme groups and engage in such actions. In a framework and policies that are starting to develop now that are referred to as counter violence and extremism (CVE), the process and dynamics of radicalization involving macro and micro elements are referred to as "push and pull" factors [24]. Some push factors include certain structural and emotional-psychological conditions that make individuals or groups have the potential for violence. Meanwhile, pull factors in the form of organizations or groups that are actively recruiting, as well as the existence of various narratives and messages that invite extremism. The interaction and the meeting of these two factors cause some of individuals or groups to be increasingly vulnerable to being mired in a circle of violence and extremism. The United Nations Global Counter-Terrorism Strategy is called a number of structural conditions which are considered to be encouraging people or groups are easily 
affected by radicalism, including: (a) unavailability of socio-economic opportunities; (b) situations of marginalization and discrimination, (c) poor governance, characterized by, among other things, many violations of human rights and weak rule of law (d) the occurrence of prolonged conflicts and not resolved, (e) ongoing radicalization in prison [25].

Some of these studies show that the rise of radicalism cannot be explained simply by appealing to a single cause or factor, but is a complex phenomenon. So the effort to deradicalize also requires a variety of approaches. Deradicalization, according to Law No. $5 / 2018$ concerning the eradication of the crime of terrorism, preaching as a process of eliminating, reducing, and changing the ideology of terrorism is carried out carefully, integrated, systematically and continuously. The process of deradicalization involves various rehabilitation, reeducation and social reintegration programs involved in acts of terror as suspects, defendants, prisoners, detainees, former detainees and individuals or groups who have been exposed to radical terrorist ideologies.

Indonesia's deradicalization program for terrorist prisoners has been well implemented under the coordination of the National Counterterrorism Agency (BNPT). Some studies assess the deradicalization program as having weaknesses in achieving rehabilitation goals, such as uncooperative prisoners and lack of supporting facilities [26]. The deradicalization approach in Indonesia tends to focus on four elements: (1) isolating prisoners involved in the deradicalization program from other terrorist prisoners; (2) providing practical incentives for prisoners to get involved, including holding them in better conditions and by providing economic assistance for themselves and their families; (3) using former militants to debate current prisoners of ideology, reasons and justifications for violence; and (4) organizing workshops to address issues such as anger management but also to develop practical skills for future work and provide new social relationships outside terrorist networks. However, many studies notes that the program is less costly, labor and less institutionalized [27].

According to Andrie eradicition is carried out and regulated independently by prison management according to their abilities and capacities. Most of these prisons do not have special programs to rehabilitate or de-radicalize terrorist prisoners. Only two prisons are considered to have adequate programs: Porong Prison (Surabaya) and Semarang Prison [28]. The de-radicalization program in Indonesian prisons can be identified by several activities, such as providing conflict management training or inviting an ulama (Islamic cleric) from the Indonesian Ulema Council (Majelis Ulama' Indonesia/MUI) to deliver speeches and discussions with terrorist detainees. An interesting finding was that most participants refused to be involved in the program. These conditions have an impact on the effectiveness of the deradicalization program. Nurezki states that the effectiveness of the de-radicalization program currently being carried out by the Indonesian government is questioned because of cases of recidivism in terror activities.

\section{Conclusion}

Prison as a place for terrorist prisoners can be an effective place in deradicalization efforts. However, at the same time, prison can also be a fertile ground for the seeds of radicalism. The social dynamics between prison officers and terrorist prisoners become a significant factor in presenting the two 'faces' of prison. Changes in the environmental situation can affect changes in a person's behavior, including terrorist prisoners in prison. This process is formed through interaction with the environment and the process of individual 
understanding of the surrounding environment situation. Understanding the individual will give birth to an attitude that influences the formation of specific behaviors in dealing with changes and environmental situations. Such a process becomes a cycle that will occur continuously in one's life to give birth to certain perceptions and actions.

\section{References}

[1] Hannah, G., Rubin, J., \& Clutterbuck, L.. Radicalization or rehabilitation: Understanding the challenge of extremist and radicalized prisoners. RAND Corporation. (2008)

[2] Hwang, J. C., Panggabean, R., \& Fauzi, I. A. The disengagement of jihadis in Poso, Indonesia. Asian Survey, 53(4), 754-777. (2013).

[3] Silke, A., \& Veldhuis, T. Countering violent extremism in prisons: A review of key recent research and critical research gaps. Perspectives on terrorism, 11(5). (2017).

[4] Suarda, I. An examination of Indonesian prison officers' experiences on deradicalisation: towards better practice (Doctoral dissertation, Queensland University of Technology); Silke, A. (Ed.). (2014). Prisons, terrorism and extremism: Critical issues in management, radicalisation and reform. Routledge. (2018).

[5] Farrington, D. P., \& Nuttall, C. P. Prison size, overcrowding, prison violence, and recidivism. Journal of Criminal Justice, 8(4), 221-231., pp.221-231; Jones, C. R. (2014). Are prisons really schools for terrorism? Challenging the rhetoric on prison radicalization. Punishment \& Society, 16(1), 74-103; Istiqomah, M. (2011). De-radicalization program in Indonesian prisons: Reformation on the correctional institution, US-China Law Review, 29. (1980).

[6] Thomas, J., \& Zaitzow, B. H. Conning or conversion? The role of religion in prison coping. The Prison Journal, 86(2), 242-259. (2006).

[7] https://nasional.kompas.com/read/2018/05/30/12294981/bnpt-ada-289-narapidana-terorisme-yangtersebar-di-113-lapas

[8] http://smslap.ditjenpas.go.id/public/grl/current/monthly.

[9] Schmid, A. P. Radicalisation, de-radicalisation, counter-radicalisation: A conceptual discussion and literature review. ICCT Research Paper, 97(1), 22. (2013).

[10] Suarda, I. An examination of Indonesian prison officers' experiences. (2018).

[11] Durkheim, E. Durkheim: The Division of Labour in Society. Macmillan International Higher Education. (2013).

[12] Nurezki, L P, A Hazy Redemption: Can Deradicalization Work in Indonesia?,dalam https://scholarbank.nus.edu.sg/handle/10635/53620 diakses pada 1 September. (2019)

[13] Useem, B., \& Reisig, M. D. Collective action in prisons: Protests, disturbances, and riots. Criminology, 37(4), 735-760. (1999).

[14] Amitai Etzioni (Ed.). Complex organizations: A sociological reader. Holt, Rinehart and Winston. (1961).

[15] Reisig, M. D. Administrative control and inmate homicide. Homicide studies, 6(1), 84-103. (2002).

[16] Andrews, D. A., Bonta, J., \& Wormith, J. S. The recent past and near future of risk and/or need assessment. Crime \& Delinquency, 52(1), 7-27. (2006).

[17] Liebling, A. and Straub, C., Identity challenges and the risks of radicalisation in high security custody. Prison Service Journal, 203.; Cilluffo, F.J., Cardash, S.L. and Whitehead, A.J., 2006. Radicalization: Behind bars and beyond borders. Brown J. World Aff., 13, (2012)

[18] Horgan, J, The Psychology of Terrorism, (London and New York, Routledge); Post, Jerrold M., 2007. The Mind of the Terrorist: The Psychology of Terrorism From The IRA to Al Qaeda, (New York, Palgrave Macmillan). (2005).

[19] Marranci, G. Wars of terror. Bloomsbury Publishing. (2015).

[20] Lamintang, P.A.F. Hukum Penitensier Indonesia.Bandung: Armico. (1984)

[21] Fox, V. Violence Behind Bars: An Explosive Report on Prison Violence in TheUnited State. (1956) 
[22] Colvin, M. "Applying Differential Coercion and Social Support Theory to Prison Organizations: The Case of the Penitentiary of New Mexico", in The Prison Journal, No.87, (2007: 367). (2007).

[23] Edgar, Kimmett\& Ian O'Donnell, "Assault in Prison: The 'Victim's' Contribution" in Brit J. Criminol, Vol. 38, No. 4, 1998; "Routine Victimisation in Prisons", in The Howard Journal, Vol. 37, No. 3, 1998; "Fear in Prison" in The Prison Journal, Vol. 79 No. 1, March 1999

[24] Horgan, Jhon G\& Mary Beth Altier, "The Future of Terrorist De-Radicalization Programs", dalam Conflict \& Security, Mei (2017)

[25] Holmer, Georgia, "Countering Violent Extremist: A Peacebulding Perspective", dalam United States Institute of Peace, September (2013)

[26] Mareta, Josefhin, (2018), "Rehabilitasi dalam Upaya Deradikalisasi Narapidana Terorisme", dalam Masalah-Masalah Hukum, Vol. 47, No. 4, Oktober (2018)

[27] Suarda, I, "A Literature Review on Indonesia's Deradicalization Proggram for Terrorist Prisoners", dalam Mimbar Hukum, Vol. 28, No. 3, Oktober (2016)

[28] Andrie, T, Kehidupan di Balik Jeruji: Terorisme dan Kehidupan Penjara di Indonesia, Institute for International Peace Building Position Paper, 2 (11). (2011). 